\title{
Implementation of baby boomer hepatitis $C$ screening and linking to care in gastroenterology practices: a multi-center pilot study
}

\author{
Zobair M. Younossi ${ }^{1,2,9^{*}}$, Louis L. LaLuna ${ }^{3}$, John J. Santoro ${ }^{4}$, Flavia Mendes ${ }^{5}$, Victor Araya ${ }^{6}$, Natarajan Ravendhran",
} Lisa Pedicone ${ }^{8}$, Idania Lio ${ }^{8}$, Fatema Nader ${ }^{2}$, Sharon Hunt ${ }^{2}$, Andrei Racila ${ }^{2}$ and Maria Stepanova ${ }^{2}$

\begin{abstract}
Background: Estimates suggest that only $20 \%$ of HCV-infected patients have been identified and $<10 \%$ treated. However, baby boomers (1945-1965) are identified as having a higher prevalence of HCV which has led the Centers for Disease Control and Prevention to make screening recommendations. The aim of this study was to implement the CDC's screening recommendations in the unique setting of gastroenterology practices in patients previously unscreened for HCV.
\end{abstract}

Methods: After obtaining patient informed consent, demographics, clinical and health-related quality of life ( $\mathrm{HRQOL}$ ) data were collected. A blood sample was screened for HCV antibody (HCV AB) using the OraQuick HCV Rapid Antibody Test. HCV AB-positive patients were tested for presence of HCV RNA and, if HCV RNA positive, patients underwent treatment discussions.

Results: We screened 2,000 individuals in 5 gastroenterology centers located close to large metropolitan areas on the East Coast (3 Northeast, 1 Mid-Atlantic and 1 Southeast). Of the screened population, 10 individuals (0.5\%) were HCV AB-positive. HCV RNA testing was performed in $90 \%(9 / 10)$ of HCV AB-positive individuals. Of those, $44.4 \%(4 / 9)$ were HCV RNA-positive, and all 4 (100\%) were linked to caregiver. Compared to HCV AB negative subjects, HCV AB-positive individuals tended to be black (20.0 vs. $5.2 \%, p=0.09)$ and reported significantly higher rates of depression: 60.0 vs. $21.5 \%, p=0.009$. These individuals also reported a significantly lower HRQOL citing having more fatigue, poorer concentration, and a decreased level of energy $(p<0.05)$.

Discussion: Although the prevalence of HCV AB-positive was low in previously unscreened subjects screened in the gastroenterology centers, the linkage to care was very high. The sample of patients used in this study may be biased, so further studies are needed to assess the effectiveness of the CDC screening recommendations.

Conclusion: Implementation of the Baby Boomer Screening for HCV requires identifying screening environement with high prevalence of $\mathrm{HCV}+$ individuals as well as an efficient process of linking them to care.

\section{Background}

Hepatitis C viral (HCV) infection is the leading cause of cirrhosis and hepatocellular carcinoma in the United States, and the most common indication for liver transplantation [1-4]. There is increasing evidence that $\mathrm{HCV}$ is a systemic disease with both hepatic and extrahepatic manifestations [1]. There is also significant evidence that $\mathrm{HCV}$ infection is associated with tremendous economic

\footnotetext{
* Correspondence: zobair.younossi@inova.org

${ }^{1}$ Center for Liver Diseases, Inova Fairfax Hospital, Falls Church, VA, USA

${ }^{2}$ Center for Outcomes Research in Liver Diseases, Washington, DC, USA

Full list of author information is available at the end of the article
}

burden including both direct and indirect costs associated with management of HCV-related hepatic and extrahepatic manifestations as well as lost years of life, impaired quality of life and work productivity [1-9] On the other hand, sustained viral response (SVR) of HCV infection has been reported to improve morbidity and mortality as well as health-related quality of life and work productivity in patients with HCV [10-13]. With the current all-oral second generation direct-acting antiviral agents, over $95 \%$ of treated patients can achieve SVR with an excellent safety profile [14-29]. 
Despite substantial gains in treating $\mathrm{HCV}$ with these new highly effective antiviral regimens, there are a number of barriers which still exist [30-34]. Of these, the two most notable barriers are difficulty in obtaining insurance funding for the new regimens and the identification of all HCV infected patients [30-34]. The current estimates suggest that only between 10-50\% of HCV infected patients in the US are currently diagnosed [31]. This is partly due to health care providers' lack of enthusiasm about the previous anti-HCV treatment regimens and their substantial side effect profile. Additionally, the recommended risk-based screening has not been effective in identifying infected patients [35]. Since 1998, the CDC has suggested HCV antibody screening of individuals with past behaviors or health indicators associated with HCV infection (e.g., history of injection drug use, hemodialysis, etc.). Despite these recommendations, more than $50 \%$ of individuals with chronic hepatitis $\mathrm{C}(\mathrm{CHC})$ continue to be unaware of their infections, leading to questions about the effectiveness of such "risk-based" screening [36, 37].

In the United States, HCV infection is most prevalent among individuals born between 1945 and 1965 accounting for approximately $75 \%$ of hepatitis Cassociated mortality [38]. Since more than $50 \%$ of infected individuals are unaware of their infection, the number of adults with $\mathrm{CHC}$ that will progress to cirrhosis, liver failure, hepatocellular carcinoma, and death is expected to increase dramatically in the coming decades $[38,39]$. Without changes to $\mathrm{CH}-\mathrm{C}$ screening, diagnosing and treatment paradigms, over the next 20 years, the total medical costs for individuals with $\mathrm{HCV}$ infection are expected to more than double, from $\$ 30$ billion to over $\$ 85$ billion [40]. Therefore, in 2012, CDC adjusted their recommendations to include a one-time hepatitis $\mathrm{C}$ screening of all individuals born between 1945 and 1965 [41]. The US Preventive Services Task Force has stepped forward and supported the CDC's recommendation for birth cohort screening as well [42].

With therapies achieving SVR in $>90 \%$ of patients, targeted testing and link to care for infected persons in this birth cohort are expected to reduce HCV-related morbidity and mortality [35]. Therefore, the aim of this study was to implement a pilot screening project in 5 real world Gastroenterology Practices to identify baby boomers infected with $\mathrm{HCV}$ and to test the feasibility of screening and linking patients to care in a specialized practice setting.

\section{Methods}

\section{Study population}

This is a multi-center study sponsored by Chronic Liver Disease Foundation that involved 5 gastroenterology practices selected by the American College of Gastroenterology. The sites were large clinical practices within metropolitan areas that had familiarity with standard preventative screening procedures (e.g., colon cancer screening) and Good Clinical Practices (i.e., informed consent, data privacy, data collection). Enrollment started in 2014 and was completed in June 2015; it was competitive and not capped at any given site. Inclusion criteria were as follows: male and female patients born between 1945 and 1965, inclusive; willingness to give written informed consent; ability to read and understand English. Patients with documented history of $\mathrm{HCV}$ antibody (HCV Ab) or HCV RNA screening were excluded. To obtain baseline information, all patients were asked to fill out two questionnaires - one with their demographic and basic clinical history and one with healthrelated quality of life information (HRQL). Each patient underwent a blood draw to obtain a sample of blood for $\mathrm{HCV}$ screening. If the patient tested positive for $\mathrm{HCV} \mathrm{Ab}, \mathrm{a}$ standard of care confirmatory test was performed.

\section{Clinical and HRQL data}

After informed consent, demographic, clinical and quality of life data were obtained. In particular, all enrolled individuals reported their age, gender, race/ethnicity and zip code. Medical history questionnaire asked about history of diabetes mellitus, hypertension, hyperlipidemia (that or high cholesterol or high triglycerides), heart disease (not specified), and about experiencing anxiety, depression, and fatigue. Individuals were also asked about recent alcohol consumption (3 or more drinks a week for a year) and about their current smoking status.

To assess fatigue, vitality, and exertion, 20 items from three widely used and extensively validated HRQL assessment instruments were selected and included into one questionnaire [43-47]. Specifically, the items were chosen from the physical functioning domain (PF) of the SF-36, the activity/energy (AE) and emotional (EM) domains of CLDQ-HCV, and the fatigue scale domain (FS) of FACITF [43-47]. The questionnaire was in English and selfadministered. The responses to individual items were collected and, after transformation to a universal scale, were averaged to a total generic HRQL score (0-100).

\section{Screening for HCV infection}

Sites were provided with commercially approved OraQuick HCV Rapid Antibody Test kits (OraSure Technologies). Each subject's blood sample was screened for HCV Ab using Oraquick anti-HCV test. An adverse event was defined as any medical occurrence in response to the administration of the OraQuick Rapid HCV Test.

Individuals who were $\mathrm{HCV}$ Ab-negative were no longer followed-up for this study. For HCV Ab-positive individuals, a standard of care confirmatory testing was ordered by the screening site (as per standard medical practice) such as HCV RNA test, and results were collected. Individuals were also counseled and educated on $\mathrm{HCV}$, 
including the use of alcohol, acetaminophen, and receiving hepatitis A and B vaccinations. The HCV Ab-positive individuals who consented to be followed also completed a four week follow-up HRQL survey. Finally, HCV RNA positive individuals were linked to care within the site practice or the geographical area and the date of the scheduled visit was recorded. The site also followed instructions regarding the local state requirements on whether a positive result had to be reported to a state health department.

\section{The study outcomes and statistical analysis}

The primary endpoint of this study was the percentage of individuals with a positive $\mathrm{HCV} \mathrm{Ab}$. The secondary endpoints were the percentages of $\mathrm{HCV}$ Ab-positive individuals who underwent confirmatory testing and were linked to care, and HRQL scores at baseline and at follow-up.

The demographic and clinical parameters of individuals who were $\mathrm{HCV}$ Ab-positive or $\mathrm{HCV}$ Ab-negative were compared using Fisher exact test or MannWhitney non-parametric test. Individual HRQL items were treated as ordinal parameters; the total HRQL score was considered continuous. A p-value of less than 0.05 was considered significant. Independent predictors of a positive $\mathrm{HCV} \mathrm{Ab}$ result were evaluated by a logistic regression using all collected clinico-demographic parameters as predictors. All analyses were run in SAS 9.3
(SAS Institute, Cary, NC). The study was approved by Copernicus IRB Board.

\section{Results}

Two thousand baby boomer individuals were consented and screened in 5 gastroenterology practices selected by American College of Gastroenterology (regions: 3 Northeast, 1 Mid-Atlantic and 1 Southeast). The demographic and clinical data is summarized in Table 1, and HRQL data is summarized in Table 2.

Screened individuals were, on average, $60 \pm 6$ years old, $40 \%$ male, $72 \%$ Caucasian, $21 \%$ Hispanic and $5 \%$ African-American. Also, $30 \%$ reported history of anxiety, $22 \%$ reported depression and $38 \%$ reported clinically overt fatigue. Furthermore, $16 \%$ had a history of diabetes, $43 \%$ had a history of hypertension, and $48 \%$ had history of hyperlipidemia. Additionally, $27.5 \%$ reported drinking alcohol $\geq 3$ drinks per week, and $10.2 \%$ reported current smoking (Table 1 ).

Of the screened population, 10 individuals $(0.5 \%)$ had positive serology for HCV. Of those, 4 (40 \%) reported history of IV drug use and $2(20 \%)$ a history of intranasal drug use, 4 (40 \%) had an unregulated tattoo, 1 (10 \%) had a history of incarceration, and 1 (10 \%) reported a history of blood transfusion before 1992 (Table 3).

The HCV RNA testing was done in $90 \%(9 / 10)$ of HCV-antibody positive individuals, and $44.4 \%(4 / 9)$

Table 1 Demographics and medical history of the screened birth cohort

\begin{tabular}{|c|c|c|c|c|}
\hline & $\mathrm{HCV} \mathrm{Ab}+$ & HCV Ab- & $p$ & All subjects \\
\hline $\mathrm{N}$ & 10 & 1,990 & & 2,000 \\
\hline Age, years & $58.4 \pm 3.2$ & $59.8 \pm 6.0$ & 0.41 & $59.8 \pm 6.0$ \\
\hline \multicolumn{5}{|l|}{ Race or ethnicity } \\
\hline Caucasian & 8 (80.0 \%) & 1429 (71.8 \%) & 0.73 & 1437 (71.9\%) \\
\hline African-American & 2 (20.0 \%) & $103(5.2 \%)$ & 0.0933 & 105 (5.3 \%) \\
\hline Hispanic & $0(0.0 \%)$ & 418 (21.0\%) & 0.13 & 418 (20.9 \%) \\
\hline Asian & $0(0.0 \%)$ & $26(1.3 \%)$ & 1.00 & 26 (1.3 \%) \\
\hline Other & $0(0.0 \%)$ & 14 (0.7 \%) & 1.00 & $14(0.7 \%)$ \\
\hline Male gender & $4(40.0 \%)$ & 793 (39.8 \%) & 1.00 & 797 (39.9 \%) \\
\hline \multicolumn{5}{|l|}{ History of: } \\
\hline Type 2 diabetes & $3(30.0 \%)$ & 308 (15.5 \%) & 0.20 & $311(15.6 \%)$ \\
\hline Hypertension & $5(50.0 \%)$ & 858 (43.4 \%) & 0.75 & $863(43.4 \%)$ \\
\hline Hyperlipidemia & $4(40.0 \%)$ & 951 (47.9 \%) & 0.76 & 955 (47.8 \%) \\
\hline Anxiety & $4(40.0 \%)$ & 600 (30.3\%) & 0.50 & 604 (30.3 \%) \\
\hline Depression & $6(60.0 \%)$ & 424 (21.5\%) & 0.0094 & 430 (21.7 \%) \\
\hline Fatigue & $6(60.0 \%)$ & 742 (37.5 \%) & 0.19 & 748 (37.6 \%) \\
\hline Heart disease & $2(20.0 \%)$ & 219 (11.1\%) & 0.31 & $221(11.1 \%)$ \\
\hline Alcohol consumption > $30 \mathrm{~g} /$ week & $3(30.0 \%)$ & $545(27.5 \%)$ & 1.00 & $548(27.5 \%)$ \\
\hline Current smoking & 3 (30.0 \%) & 199 (10.1\%) & 0.0731 & 202 (10.2 \%) \\
\hline
\end{tabular}


Table 2 Quality of life in the screened birth cohort

\begin{tabular}{|c|c|c|c|c|c|c|}
\hline Question text & Range $^{a}$ & Instrument, item (domain) & $\begin{array}{l}\mathrm{HCV} A \mathrm{~b} \\
+(\mathrm{N}=10)\end{array}$ & $\begin{array}{l}\text { HCV Ab- } \\
(N=1,889)\end{array}$ & $p$ & All subjects \\
\hline $\begin{array}{l}\text { How much have you been tired or fatigued } \\
\text { during the last } 2 \text { weeks? }\end{array}$ & $1-7$ & CLDQ-HCV Q1 (AE) & $3.60 \pm 1.96$ & $4.82 \pm 1.70$ & 0.0412 & $4.82 \pm 1.70$ \\
\hline $\begin{array}{l}\text { How much difficulty have you had with } \\
\text { bending, lifting, or stooping in the last } 2 \text { weeks? }\end{array}$ & $1-7$ & CLDQ-HCV Q4 (AE) & $5.10 \pm 1.85$ & $5.53 \pm 1.69$ & 0.37 & $5.53 \pm 1.69$ \\
\hline $\begin{array}{l}\text { How often during the last } 2 \text { weeks have you } \\
\text { felt a decreased level of energy? }\end{array}$ & $1-7$ & CLDQ-HCV Q7 (AE) & $3.80 \pm 2.10$ & $4.98 \pm 1.69$ & 0.0155 & $4.97 \pm 1.69$ \\
\hline $\begin{array}{l}\text { How often during the last } 2 \text { weeks have you } \\
\text { felt depressed? }\end{array}$ & $1-7$ & CLDQ-HCV Q16 (EM) & $4.40 \pm 2.12$ & $5.88 \pm 1.49$ & 0.0144 & $5.87 \pm 1.50$ \\
\hline $\begin{array}{l}\text { How much of the time during the last } 2 \text { weeks } \\
\text { have you had problems concentrating? }\end{array}$ & $1-7$ & CLDQ-HCV Q18 (AE) & $4.80 \pm 1.75$ & $5.70 \pm 1.47$ & 0.0471 & $5.70 \pm 1.47$ \\
\hline \multicolumn{7}{|l|}{$\begin{array}{l}\text { The following questions are about activities you } \\
\text { might do during a typical day. Does your health } \\
\text { now limit you in these activities? If so, how much? }\end{array}$} \\
\hline $\begin{array}{l}\text { Vigorous activities, such as running, lifting heavy } \\
\text { objects, participating in strenuous sports }\end{array}$ & $1-3$ & SF-36 PF01 & $2.10 \pm 0.99$ & $2.13 \pm 0.82$ & 0.41 & $2.13 \pm 0.82$ \\
\hline $\begin{array}{l}\text { Moderate activities, such as moving a table, } \\
\text { pushing a vacuum cleaner, bowling, or playing golf }\end{array}$ & $1-3$ & SF-36 PF02 & $2.20 \pm 1.03$ & $2.60 \pm 0.67$ & 0.0122 & $2.59 \pm 0.67$ \\
\hline Lifting or carrying groceries & $1-3$ & SF-36 PF03 & $2.30 \pm 0.95$ & $2.67 \pm 0.60$ & 0.0450 & $2.67 \pm 0.60$ \\
\hline Climbing several flights of stairs & $1-3$ & SF-36 PF04 & $2.20 \pm 0.92$ & $2.47 \pm 0.72$ & 0.29 & $2.47 \pm 0.72$ \\
\hline Climbing one flight of stairs & $1-3$ & SF-36 PF05 & $2.20 \pm 1.03$ & $2.69 \pm 0.60$ & 0.0064 & $2.68 \pm 0.61$ \\
\hline Bending, kneeling, or stooping & $1-3$ & SF-36 PF06 & $2.40 \pm 0.84$ & $2.47 \pm 0.70$ & 0.65 & $2.47 \pm 0.70$ \\
\hline Walking more than a mile & $1-3$ & SF-36 PF07 & $2.20 \pm 0.79$ & $2.46 \pm 0.76$ & 0.22 & $2.46 \pm 0.76$ \\
\hline Walking several hundred yards & $1-3$ & SF-36 PF08 & $2.10 \pm 0.88$ & $2.66 \pm 0.64$ & 0.0195 & $2.66 \pm 0.64$ \\
\hline Walking one hundred yards & $1-3$ & SF-36 PF09 & $2.10 \pm 0.99$ & $2.73 \pm 0.58$ & 0.0063 & $2.72 \pm 0.59$ \\
\hline Bathing or dressing yourself & $1-3$ & SF-36 PF10 & $2.60 \pm 0.84$ & $2.86 \pm 0.44$ & 0.10 & $2.86 \pm 0.44$ \\
\hline \multicolumn{7}{|l|}{$\begin{array}{l}\text { Please indicate how true each statement has } \\
\text { been for you during the past } 7 \text { days. }\end{array}$} \\
\hline I feel fatigued & $4-0$ & FACIT-F HI7 (FS) & $2.10 \pm 1.45$ & $1.11 \pm 1.20$ & 0.0107 & $1.11 \pm 1.20$ \\
\hline I feel tired & $4-0$ & FACIT-F An2 (FS) & $2.00 \pm 1.49$ & $1.25 \pm 1.16$ & 0.15 & $1.25 \pm 1.16$ \\
\hline I have trouble starting things because I am tired & $4-0$ & FACIT-F An3 (FS) & $1.70 \pm 1.64$ & $0.80 \pm 1.12$ & 0.0148 & $0.80 \pm 1.13$ \\
\hline I have energy & $0-4$ & FACIT-F An5 (FS) & $1.80 \pm 0.63$ & $2.41 \pm 1.18$ & 0.0352 & $2.41 \pm 1.18$ \\
\hline I need help doing my usual activities & $4-0$ & FACIT-F An14 (FS) & $0.80 \pm 0.79$ & $0.37 \pm 0.86$ & 0.0100 & $0.37 \pm 0.86$ \\
\hline Average score & $0-100$ & generic & $58.9 \pm 32.5$ & $76.3 \pm 21.3$ & 0.071 & $76.2 \pm 21.4$ \\
\hline
\end{tabular}

${ }^{a}$ the range is from the worst to the best health status. Higher scores indicate better HRQOL

were found to be HCV RNA-positive, $100 \%$ of whom were counseled and linked to care by establishing an appointment regarding their $\mathrm{HCV}$. Compared to $\mathrm{HCV}$-antibody negative individuals, those who were $\mathrm{HCV}$-antibody positive tended to be African-Americans (20.0 vs. $5.2 \%, p=0.09)$ and report more frequently a history of depression: 60.0 vs. $21.5 \%(p=0.009)$ (Table 1). Multivariate analysis with logistic regression showed that depression was the only clinical parameter independently associated with being HCV-antibody positive [odds ratio (95\% confidence interval $)=5.49(1.54-19.54)]$.

The HCV-antibody positive individuals also had lower quality of life as documented by more fatigue, poorer concentration, less activity, and decreased levels of energy (all p-values $<0.05$ ) (Table 2). The four weeks follow-up HRQOL questionnaire showed no significant changes (all $p>0.1$ ) from the baseline values in individuals who tested positive for HCV (Table 4).

\section{Discussion}

This is the largest HCV screening program in the baby boomers who presented to a specialty gastroenterology practices for clinical care. The data suggest that the prevalence of $\mathrm{HCV}$ antibody positivity in this particular study setting (subjects visiting GE practices who have not previously been identified) is relatively low $(0.5 \%)$ as compared to the reported $\mathrm{HCV} \mathrm{AB}$ positive rate in the general population at $4.1 \%$ for males and $1.6 \%$ for females [48]. It is important to note that, in addition to a bias introduced solely by the fact of patients being seen 
Table 3 Additional socio-demographic information and link to care for $\mathrm{HCV} A b+$ patients $(N=10)$

\begin{tabular}{ll}
\hline & $\mathrm{N}(\%)$ or mean \pm std.dev. \\
\hline Confirmed HCV ab+ & $10(100.0 \%)$ \\
HCV RNA-positive ${ }^{a}$ & $4(44.4 \%)$ \\
ALT, IU/mL & $32.8 \pm 35.4$ \\
AST, IU/mL & $25.2 \pm 21.7$ \\
History of: & \\
Past or current IV drug use & $4(40.0 \%)$ \\
Blood transfusions before 1992 & $1(10.0 \%)$ \\
Long-term hemodialysis & $0(0.0 \%)$ \\
Incarceration & $1(10.0 \%)$ \\
Being born to HCV-infected & $0(0.0 \%)$ \\
mother & $2(20.0 \%)$ \\
Intranasal drug use & $4(40.0 \%)$ \\
Unregulated tattoo or other & \\
percutaneous exposure & \\
Counseled about: & $9(90.0 \%)$ \\
Acetaminophen use & $10(100.0 \%)$ \\
Alcohol consumption & $9(90.0 \%)$ \\
Hepatitis A and B vaccination & $9(90.0 \%)$ \\
Linked to care & $6(60 \%)$ \\
Completed follow-up questionnaire &
\end{tabular}

a one HCV ab + patient refused to give blood sample

in tertiary care centers in a small sample of localities, our study excluded individuals who had already been diagnosed with $\mathrm{HCV}$ or had been screened for $\mathrm{HCV}$ previously due to meeting certain high risk criteria. Therefore, the prevalence rate reported in this study is likely substantially lower than one that could have been obtained in a community-based screening setting, and neither does it reflect the true $\mathrm{HCV}$ prevalence in the GE practices (due to exclusion of those with an existing diagnosis of $\mathrm{HCV}$ ).

Our study also indicates that about half of the individuals who were $\mathrm{HCV}$ antibody positive were viremic. In this HCV cohort, risk factors reported were similar to those previously known for HCV viremic patients [1-4]. Furthermore, African Americans tended to have a higher prevalence of $\mathrm{HCV}$ which is also consistent with previous reports. Additionally, those testing $\mathrm{HCV}$ positive had more depression independently associated with their $\mathrm{HCV}$ positivity status. All HCV positive individuals were linked to follow-up care through scheduled appointments. This is a significant finding as this part of the screening, diagnosis, and treatment continuum has been a challenge in other settings such as emergency rooms [2].

These data are similar to those reported by Sears et al. from a single GE practice for baby boomers undergoing colonoscopy. In fact, in that study, only one of 376 subjects $(0.27 \%)$ was HCV RNA positive, a rate almost identical to our $\mathrm{HCV}$ viremic individuals (0.2 \%) [3]. There are a number of potential explanations for the relatively low prevalence of $\mathrm{HCV}$ in $\mathrm{GE}$ practices. The most important explanation may be related to the type of patients who are seen in GE practices - they are most likely insured with the majority (72\%) being Caucasians.

The low prevalence of $\mathrm{HCV}$ in this special population as compared to a community-based approach is of special importance as specialty practices may not be the best places to screen for HCV but may provide the best avenue for follow-up care once identified. For instance, Galbraith et al. reported screening of baby boomers in an emergency room. These authors reported an $11.1 \%$ positive $\mathrm{HCV}$ antibody rate with $68 \%$ being viremic. On the other hand, only $54 \%$ of $\mathrm{HCV}$ viremic patients were able to be contacted and $38 \%$ were able to be scheduled for follow-up appointments indicating a significant drop-off [2].

In addition to high prevalence of $\mathrm{HCV}$ in the baby boomers seen in the emergency department, the prevalence rates are also high for baby boomers screened in the hospital setting. In a study by Turner et al., the prevalence of newly diagnosed HCV in hospitalized baby boomers was $8 \%$ [4]. Finally, in a study reported by Morano et al., baby boomers were screened either by point of care (POC) HCV antibody testing or traditional serologic testing in the setting of a mobile medical clinic. The reported prevalence of $\mathrm{HCV}$ positivity in this cohort was $6.2 \%$. Individuals who underwent POC testing were much more likely (93.8 \%) than traditional serologic testing $(18.2 \%)$ to be linked to care [5]. In a recent modeling study from 15 countries worldwide, investigators found that diagnosing and treating a small proportion of patients with high efficacy drugs can have a significant effect on the reduction of the HCV disease burden within the countries studied [49]. At the same time, the authors caution that the best scenario would be to have increased diagnosis and treatment with high efficacy treatments to have the best results. Others, though, argue that the model used was not a dynamic model and thus may not capture any new infection or reinfections so may overestimate the true impact of the use of high efficacy drugs [50].

These findings not only assist healthcare workers in identifying better areas for the identification of HCV but may assist healthcare workers in providing a better method to link screening with follow-up care. Link to care is important to deliver the highly effective antiviral treatment to patients with HCV. Our data suggest high rates of linking to care for patients who are HCVpositive to a GE clinic. Nevertheless, given the small sample size, the generalizability of this data must be interpreted with caution. Furthermore, if a GE clinic is 
Table 4 Follow-up HRQL questionnaire in $\mathrm{HCV} \mathrm{Ab}+$ patients $(N=6)$

\begin{tabular}{|c|c|c|c|c|}
\hline Question text & Range $^{a}$ & Instrument, item (domain) & baseline & 4 week f/u \\
\hline $\begin{array}{l}\text { How much have you been tired or fatigued } \\
\text { during the last } 2 \text { weeks? }\end{array}$ & $1-7$ & CLDQ-HCV, Q1 (AE) & $4.00 \pm 1.26$ & $4.50 \pm 1.64$ \\
\hline $\begin{array}{l}\text { How much difficulty have you had with bending, } \\
\text { lifting, or stooping in the last } 2 \text { weeks? }\end{array}$ & $1-7$ & CLDQ-HCV, Q4 (AE) & $5.17 \pm 1.83$ & $5.33 \pm 1.37$ \\
\hline $\begin{array}{l}\text { How often during the last } 2 \text { weeks have you felt } \\
\text { a decreased level of energy? }\end{array}$ & $1-7$ & CLDQ-HCV, Q7 (AE) & $4.00 \pm 1.55$ & $4.50 \pm 1.64$ \\
\hline $\begin{array}{l}\text { How often during the last } 2 \text { weeks have you felt } \\
\text { depressed? }\end{array}$ & $1-7$ & CLDQ-HCV, Q16 (EM) & $5.17 \pm 1.94$ & $5.00 \pm 1.55$ \\
\hline $\begin{array}{l}\text { How much of the time during the last } 2 \text { weeks } \\
\text { have you had problems concentrating? }\end{array}$ & $1-7$ & CLDQ-HCV, Q18 (AE) & $5.17 \pm 1.17$ & $5.50 \pm 1.05$ \\
\hline \multicolumn{5}{|l|}{$\begin{array}{l}\text { The following questions are about activities you might } \\
\text { do during a typical day. Does your health now limit } \\
\text { you in these activities? If so, how much? }\end{array}$} \\
\hline $\begin{array}{l}\text { Vigorous activities, such as running, lifting heavy objects, } \\
\text { participating in strenuous sports }\end{array}$ & $1-3$ & SF-36, PF01 (PF) & $2.17 \pm 0.98$ & $2.00 \pm 0.89$ \\
\hline $\begin{array}{l}\text { Moderate activities, such as moving a table, pushing a } \\
\text { vacuum cleaner, bowling, or playing golf }\end{array}$ & $1-3$ & SF-36, PF02 (PF) & $2.33 \pm 1.03$ & $2.33 \pm 0.82$ \\
\hline Lifting or carrying groceries & $1-3$ & SF-36, PF03 (PF) & $2.50 \pm 0.84$ & $2.33 \pm 0.82$ \\
\hline Climbing several flights of stairs & $1-3$ & SF-36, PF04 (PF) & $2.33 \pm 0.82$ & $2.17 \pm 0.98$ \\
\hline Climbing one flight of stairs & $1-3$ & SF-36, PF05 (PF) & $2.33 \pm 1.03$ & $2.17 \pm 0.98$ \\
\hline Bending, kneeling, or stooping & $1-3$ & SF-36, PF06 (PF) & $2.50 \pm 0.84$ & $2.00 \pm 0.89$ \\
\hline Walking more than a mile & $1-3$ & SF-36, PF07 (PF) & $2.17 \pm 0.75$ & $2.17 \pm 0.98$ \\
\hline Walking several hundred yards & $1-3$ & SF-36, PF08 (PF) & $2.00 \pm 0.89$ & $2.33 \pm 0.82$ \\
\hline Walking one hundred yards & $1-3$ & SF-36, PF09 (PF) & $2.00 \pm 1.10$ & $2.33 \pm 0.82$ \\
\hline Bathing or dressing yourself & $1-3$ & SF-36, PF10 (PF) & $2.67 \pm 0.82$ & $2.67 \pm 0.82$ \\
\hline \multicolumn{5}{|l|}{$\begin{array}{l}\text { Please indicate how true each statement has been for } \\
\text { you during the past } 7 \text { days. }\end{array}$} \\
\hline I feel fatigued & $4-0$ & FACIT-F HI7 (FS) & $2.00 \pm 1.10$ & $1.33 \pm 1.51$ \\
\hline I feel tired & $4-0$ & FACIT-F An2 (FS) & $2.00 \pm 1.41$ & $1.50 \pm 1.38$ \\
\hline I have trouble starting things because I am tired & $4-0$ & FACIT-F An3 (FS) & $1.33 \pm 1.37$ & $1.33 \pm 1.21$ \\
\hline I have energy & $0-4$ & FACIT-F An5 (FS) & $2.00 \pm 0.63$ & $1.67 \pm 0.52$ \\
\hline I need help doing my usual activities & $4-0$ & FACIT-F An14 (FS) & $0.50 \pm 0.55$ & $1.00 \pm 0.89$ \\
\hline Average score & $0-100$ & Generic & $63.1 \pm 29.9$ & $63.4 \pm 27.9$ \\
\hline
\end{tabular}

${ }^{a}$ the range is from the worst to the best health status

not available another suggested method is the use of Innovative Mobile Clinics equipped with POC testing for $\mathrm{HCV}$ that use established pathways [5]. Using mobile clinics allow for $\mathrm{HCV}$-positive patients to be immediately linked to care.

In this study, we also assessed the quality of life in all patients at baseline before they knew their HCV infection status as there are previous data which suggest that knowledge about HCV diagnosis can impair HRQL [51]. We have found that at baseline patients who were $\mathrm{HCV}$ $\mathrm{AB}+$ had more impairment of their HRQL having more complaints of fatigue, poorer concentration, less activity, and decreased levels of energy as compared to those who were HCV AB-. This is consistent with previous data which have demonstrated that HCV-infected patients suffer from HRQL impairment possibly due to the potential effects of the virus crossing the blood-brain barrier and affecting the brain chemistry directly [52-54]. In our study, for the patients who were $\mathrm{HCV} \mathrm{AB+,} \mathrm{a} \mathrm{follow-}$ up survey was administered 4 weeks after their initial diagnosis, and there were no statistically significant change in their reported HRQL indicating that knowing the status of being $\mathrm{HCV} \mathrm{AB}+$ did not influence their HRQL. However, the small sample size of our study may have contributed to our inability to detect this difference in the HRQOL scores.

One of the limitation of this study was the study population referred to a GE practice indicating access to insurance coverage for consultative services and colonoscopy. This could potentially introduce a bias by excluding uninsured individuals who are known to have high prevalence of HCV (30). Another limitation of our study was our 
focus on "the age cohort" as the risk factor for HCV. Although this was done to determine the prevalence of $\mathrm{HCV}$ solely based on the age-based risk factor, other risks were not included.

\section{Conclusions}

In summary, our data show that the outcome of screening and then linkage to care for the baby boomers found to be $\mathrm{HCV}$-positive is feasible but may depend on the setting. In this study, GE practices appeared to have a low prevalence of $\mathrm{HCV}$, but the linkage to care occurred universally. Therefore, a strategy to maximize both the yield of $\mathrm{HCV}$ screening and linkage to care with appropriate providers will be critical for identifying and successfully treating patients infected with $\mathrm{HCV}$.

\section{Competing interests}

ZMY is a consultant to Abbvie, Gilead, BMS and GSK. Other authors have no competing interest.

\section{Authors' contributions}

ZMY-Primary investigator, research design, oversight, writing and editing the manuscript. LLLaL- Principal Investigator, subject enrollment and editing the manuscript. JJS- Principal Investigator, subject enrollment and editing the manuscript. FM- Principal Investigator, subject enrollment and editing the manuscript. VA- Principal Investigator, subject enrollment and editing the manuscript. NR- Principal Investigator, subject enrollment and editing the manuscript. LP-Research design, oversight, writing and editing the manuscript. IL- Research design, monitoring and editing the manuscript. FN-Database Management, writing and editing the manuscript. SH-Data design and review. AR-Data design and database development. All authors read and approved the final manuscript.

\section{Funding source}

Chronic Liver Disease Foundation (CLDF), Clark, NJ.

\section{Disclosures}

MS, LDP, IL, SH, FN, AR, LL, JS, FM, VA and NR - Nothing to Disclose. ZYM Consulting: Gilead, BMS, Abbvie, GSK.

\section{Author details}

${ }^{1}$ Center for Liver Diseases, Inova Fairfax Hospital, Falls Church, VA, USA. ${ }^{2}$ Center for Outcomes Research in Liver Diseases, Washington, DC, USA. ${ }^{3}$ Digestive Disease Associates, Wyomissing, PA, USA. ${ }^{4}$ AGA Clinical Research Associates, LLC, Egg Harbor Township, NJ, USA. ${ }^{5}$ GastroHealth, Miami, FL, USA. ${ }^{6}$ Central Bucks Specialists, Gastroenterology, Doylestown, PA, USA. ${ }^{7}$ Digestive Diseases Associates, Catonsville, MD, USA. ${ }^{8}$ Cantara Clinical Solutions, LLC, Morristown, NJ, USA. ${ }^{9}$ Betty and Guy Beatty Center for Integrated Research, Claude Moore Health Education and Research Building, 3300 Gallows Road, Falls Church, VA 22042, USA.

Received: 13 November 2015 Accepted: 17 February 2016 Published online: 04 April 2016

\section{References}

1. Younossi ZM, Kanwal F, Saab S, Brown KA, El-Serag HB, Kim WR, Ahmed A, Kugelmas M, Gordon SC. The impact of hepatitis C burden: an evidencebased approach. Aliment Pharmacol Ther. 2014;39(5):518-31.

2. Galbraith JW, Franco RA, Donnelly JP, Rodgers JB, Morgan JM, Viles AF, Overton ET, Saag MS, Wang HE. Unrecognized chronic hepatitis C virus infection among baby boomers in the emergency department. Hepatology. 2015;61(3):776-82. doi:10.1002/hep.27410. Epub 2015 Jan 28.

3. Sears DM, Cohen DC, Ackerman K, Ma JE, Song J. Birth cohort screening for chronic hepatitis during colonoscopy appointments. Am J Gastroenterol. 2013;108(6):981-9. doi:10.1038/ajg.2013.50. Epub 2013 Mar 19.

4. Turner BJ, Taylor BS, Hanson, Perez ME, Hernandez L, Villarreal R, Veerapaneni P, Fiebelkorn K. Implementing hospital-based baby boomer hepatitis c virus screening and linkage to care: Strategies, results, and costs. J Hosp Med. 2015 May 29. doi: 10.1002/jhm.2376. [Epub ahead of print].

5. Morano JP, Zelenev A, Lombard A, Marcus R, Gibson BA, Altice FL. Strategies for hepatitis $C$ testing and linkage to care for vulnerable populations: pointof-care and standard HCV testing in a mobile medical clinic. Community Health. 2014;39(5):922-34. doi:10.1007/s10900-014-9932-9.

6. Rosenthal E, Cacoub P. Extrahepatic manifestations in chronic hepatitis C virus carriers. Lupus. 2015;24(4-5):469-82. doi:10.1177/0961203314556140.

7. Younossi ZM, Singer ME, Mir HM, Henry L, Hunt S. Impact of interferon free regimens on clinical and cost outcomes for chronic hepatitis $\mathrm{C}$ genotype 1 patients. J Hepatol. 2014;60(3):530-7. doi:10.1016/j.jhep.2013.11.009. Epub 2013 Nov 19.

8. Coretti S, Romano F, Orlando V, Codella P, Prete S, Di Brino E, Ruggeri M. Economic evaluation of screening programs for hepatitis $C$ virus infection: evidence from literature. Risk Manag Healthc Policy. 2015;8:45-54. doi:10. 2147/RMHP.S56911.eCollection2015.

9. Estes C, Abdel-Kareem M, Abdel-Razek W, Abdel-Sameea E, Abuzeid M, Gomaa A, Osman W, Razavi H, Zaghla H, Waked I. Economic burden of hepatitis $C$ in Egypt: the future impact of highly effective therapies.Aliment Pharmacol Ther. 2015 Jul 22. doi: 10.1111/apt.13316. [Epub ahead of print].

10. John-Baptiste AA, Tomlinson G, Hsu PC, Krajden M, Heathcote EJ, Laporte A, Yoshida EM, Anderson FH, Krahn MD. Sustained responders have better quality of life and productivity compared with treatment failures long after antiviral therapy for hepatitis C. Am J Gastroenterol. 2009;104(10):2439-48. doi:10.1038/ajg.2009.346. Epub 2009 Jun 30.

11. North CS, Hong BA, Adewuyi SA, Pollio DE, Jain MK, Devereaux R, Quartey NA, Ashitey S, Lee WM, Lisker-Melman M. Hepatitis C treatment and SVR: the gap between clinical trials and real-world treatment aspirations. Gen Hosp Psychiatry. 2013;35(2):122-8. doi:10.1016/j.genhosppsych.2012.11.002. Epub 2012 Dec 6.

12. Younossi ZM, Stepanova M, Sulkowski M, Naggie S, Hunt SH. All Oral Therapy With Sofosbuvir Plus Ribavirin For the Treatment of Chronic Hepatitis C in Patients Co-infected With HIV (PHOTON-1 and PHOTON 2): The Impact on Patient-Reported Outcomes. J Infect Dis. 2015;212(3):367-77. doi:10.1093/infdis/jiv005. Epub 2015 Jan 12.

13. Bonkovsky HL, Snow KK, Malet PF, Back-Madruga C, Fontana RJ, Sterling RK, Kulig CC, Di Bisceglie AM, Morgan TR, Dienstag JL, Ghany MG, Gretch DR, HALT-C Trial Group. Health-related quality of life in patients with chronic hepatitis $C$ and advanced fibrosis. J Hepatol. 2007:46(3):420-31. Epub 2006 Nov 27.

14. Fazel Y, Lam B, Golabi P, Younossi Z. Safety analysis of sofosbuvir and ledipasvir for treating hepatitis C. Expert Opin Drug Saf. 2015;14(8):1317-26. doi:10.1517/14740338.2015.1053868. Epub 2015 Jun 4.

15. Lawitz E, Mangia A, Wyles D, Rodriquez-Torres M, Hassanein T, Gordon SC, Schultz M, Davis MN, Kayali Z, Reddy KR, Jacobson IM, Kowdley KV, Nyberg L, Subramanian GM, Hyland RH, Arterburn S, Jiang D, McNally J, Brainard D, Symonds WT, McHutchison JG, Sheikh AM, Younossi Z, Gane EJ. Sofosbuvir for previously untreated chronic hepatitis C infection. N Engl J Med. 2013;368(20):1878-87. doi:10.1056/ NEJMoa1214853. Epub 2013 Apr 23.

16. Poordad F, Lawitz E, Kowdley KV, Cohen DE, Podsadecki T, Siggelkow S, Heckaman M, Larsen L, Menon R, Koev G, Tripathi R, Pilot-Matias T, Bernstein B. Exploratory study of oral combination antiviral therapy for hepatitis C. N Engl J Med. 2013;368(1):45-53. doi:10.1056/NEJMoa1208809.

17. Jacobson IM, Gordon SC, Kowdley KV, Yoshida EM, Rodriguez-Torres M, Sulkowski MS, Shiffman ML, Lawitz E, Everson G, Bennett M, Schiff E, Al-Assi MT, Subramanian GM, An D, Lin M, McNally J, Brainard D, Symonds WT, McHutchison JG, Patel K, Feld J, Pianko S, Nelson DR, POSITRON Study, FUSION Study. Sofosbuvir for hepatitis C genotype 2 or 3 in patients without treatment options. N Engl J Med. 2013;368(20):1867-77. doi:10. 1056/NEJMoa1214854. Epub 2013 Apr 23.

18. Afdhal N, Zeuzem S, Kwo P, Chojkier M, Gitlin N, Puoti M, Romero-Gomez M, Zarski JP, Agarwal K, Buggisch P, Foster GR, Bräu N, Buti M, Jacobson IM, Subramanian GM, Ding $X$, Mo H, Yang JC, Pang PS, Symonds WT, McHutchison JG, Muir AJ, Mangia A, Marcellin P, ION-1 Investigators. Ledipasvir and sofosbuvir for untreated HCV genotype 1 infection. N Engl J Med. 2014;370(20):1889-98. doi:10.1056/NEJMoa1402454. Epub 2014 Apr 11.

19. Afdhal N, Reddy KR, Nelson DR, Lawitz E, Gordon SC, Schiff E, Nahass R, Ghalib R, Gitlin N, Herring R, Lalezari J, Younes ZH, Pockros PJ, Di Bisceglie AM, Arora S, Subramanian GM, Zhu Y, Dvory-Sobol H, Yang JC, Pang PS, Symonds WT, McHutchison JG, Muir AJ, Sulkowski M, Kwo P, ION-2 Investigators. Ledipasvir and sofosbuvir for previously treated HCV genotype 1 infection. N Engl J Med. 2014:370(16):1483-93. doi:10.1056/ NEJMoa1316366. Epub 2014 Apr 11. 
20. Zeuzem S, Dusheiko GM, Salupere R, Mangia A, Flisiak R, Hyland RH, Illeperuma A, Svarovskaia E, Brainard DM, Symonds WT, Subramanian GM, McHutchison JG, Weiland O, Reesink HW, Ferenci P, Hézode C, Esteban R, VALENCE Investigators. Sofosbuvir and ribavirin in HCV genotypes 2 and 3. N Engl J Med. 2014;370(21):1993-2001. doi:10.1056/NEJMoa1316145. Epub 2014 May 4.

21. Kowdley KV, Gordon SC, Reddy KR, Rossaro L, Bernstein DE, Lawitz E, Shiffman ML, Schiff E, Ghalib R, Ryan M, Rustgi V, Chojkier M, Herring R, Di Bisceglie AM, Pockros PJ, Subramanian GM, An D, Svarovskaia E, Hyland RH, Pang PS, Symonds WT, McHutchison JG, Muir AJ, Pound D, Fried MW, ION-3 Investigators. Ledipasvir and sofosbuvir for 8 or 12 weeks for chronic HCV without cirrhosis. N Engl J Med. 2014;370(20):1879-88. doi:10.1056/ NEJMoa1402355. Epub 2014 Apr 10

22. Dalgard O, Bjøro K, Ring-Larsen H, Bjornsson E, Holberg-Petersen M, Skovlund E, Reichard O, Myrvang B, Sundelöf B, Ritland S, Hellum K, Frydén A, Florholmen J, Verbaan H, North-C Group. Pegylated interferon alfa and ribavirin for 14 versus 24 weeks in patients with hepatitis $C$ virus genotype 2 or 3 and rapid virological response. Hepatology. 2008;47(1):35-42.

23. Press release- http://www.prnewswire.com/news-releases/abbviecompletes-largest-phase-iii-program-of-an-all-oral-interferon-free-therapyfor-the-treatment-of-hepatitis-c-genotype-1-242911871.html Last accessed on 30 July 2015

24. Nachega JB, Parienti J, Olalekan J, Uthman A, Gross R, Dowdy DW, Sax DE, Gallant JE, Mugavero MJ, Mills EJ, Giordano TP. Lower Pill Burden and OnceDaily Antiretroviral Treatment Regimens for HIV Infection: A Meta-Analysis of Randomized Controlled Trials. Clin Infect Dis. 2014;58(9):1297-307.

25. Kowdley KV, Lawitz E, Poordad F, et al. Safety and efficacy of interferon-free regimens of $A B T-450 / r, A B T-267$. ABT-333 \pm ribavirin in patients with chronic HCV GT1 infection: results from the Aviator study. Poster presented at the 48th Annual Meeting of the European Association for the Study of the Liver; April 24-28, 2013; Amsterdam, The Netherlands.

26. Baran RW, Xie W, Liu Y, Cohen DE, Gooch K. Health related quality of Life (HRQoL), health state, function and wellbeing of chronic HCV patients treated with interferon-free, oral DAA regimens: patient reported outcome (PRO) results from the Aviator study. Poster presented at: 64th Annual Meeting of the American Association for the Study of Liver Disease: Nov 1-5 2013: Washington, DC. P 1113.

27. Press release: OLYSIO ${ }^{\mathrm{TM}}$ (simeprevir) Receives FDA Approval for Combination Treatment of Chronic Hepatitis C. Obtained from the world wide web at http://www.jnj.com/news/all/OLYSIO-simeprevir-Receives-FDA-Approval-forCombination-Treatment-of-Chronic-Hepatitis-C. Last accessed on 30 July 2015.

28. Scott J, Rosa K, Fu M, Cerri K, Peeters M, Beumont M, Zeuzem S, Evon DM, Gilles L. Fatigue during treatment for hepatitis $C$ virus: results of self-reported fatigue severity in two Phase Ilb studies of simeprevir treatment in patients with hepatitis C virus genotype 1 infection. BMC Infect Dis. 2014;14(1):465. doi:10.1186/1471-2334-14-465.

29. Jacobson IM, Dore GJ, Foster GR, Fried MW, Radu M, Rafalsky W, Moroz L, Craxi A, Peeters M, Lenz O, Ouwerkerk-Mahadevan S, De La Rosa G, Kalmeijer R, Scott J, Sinha R, Beumont-Mauviel M. Simeprevir with pegylated interferon alfa 2a plus ribavirin in treatment-naive patients with chronic hepatitis $C$ virus genotype 1 infection (QUEST-1): a phase 3, randomised, double-blind, placebocontrolled trial. Lancet. 2014:384(9941):403-13. doi:10.1016/S01406736(14)60494-3. Epub 2014 Jun 4.

30. Stepanova M, Younossi ZM. Interferon-Free Regimens for Chronic Hepatitis C: Barriers Due to Treatment Candidacy and Insurance Coverage. Dig Dis Sci. 2015 May 19. doi: 10.1007/s10620-015-3709-6.

31. McGowan CE, Fried MW. Barriers to hepatitis C treatment. Liver Int. 2012;32 Suppl 1:151-6. doi:10.1111/j.1478-3231.2011.02706.x.

32. Gundlapalli AV, Nelson RE, Haroldsen C, Carter ME, LaFleur J. Correlates of Initiation of Treatment for Chronic Hepatitis C Infection in United States Veterans, 2004-2009. PLoS One. 2015;10(7), e0132056. doi:10.1371/journal. pone.0132056.eCollection2015.

33. Appleby J. VA, California Panels Urge Costly Hepatitis C Drugs For Sickest Patients. April 17,2014. Obtained from the world wide web at http://www. kaiserhealthnews.org/Stories/2014/April/17/hepatitis-c-sovaldi-panels-urgeapproval.aspx. Last accessed on Jul 30, 2015.

34. Stepanova M, Kanwal F, El-Serag H, Younossi ZM. Insurance Status and Treatment Candidacy of Hepatitis C Patients: Analysis of Population-based Data from the United States. Hepatology. 2011;53(3):737-45.

35. Cohn J, Roberts T, Amorosa V, Lemoine M, Hill A. Simplified diagnostic monitoring for hepatitis $C_{\text {, }}$ in the new era of direct-acting antiviral treatment. Curr Opin HIV AIDS. 2015 Jul 17. [Epub ahead of print]
36. U.S. Department Of Health And Human Services/Centers for Disease Control and Prevention (CDC). Recommendations for Prevention and Control of Hepatitis C Virus (HCV) Infection and HCV-Related Chronic Disease. MMWR, Oct 16, 1998. Last accessed on 30 July 2015 at http://www.cdc.gov/mmwr/ PDF/rr/rr4719.PDF

37. Younossi ZM, Stepanova M, Afendy M, Lam BP, Mishra A. Knowledge about infection is the only predictor of treatment in patients with chronic hepatitis C. J Viral Hepat. 2013;20(8):550-5.

38. U.S. Department Of Health And Human Services/Centers for Disease Control and Prevention (CDC). HEPATITIS C: Why Baby Boomers Should Get Tested. Available at: http://www.cdc.gov/knowmorehepatitis/Media/PDFs/FactSheetBoomers.pdf. Last accessed at 30 July 2015.

39. Galbraith JW, Donnelly JP, Franco RA, Overton ET, Rodgers JB, Wang HE. National estimates of healthcare utilization by individuals with hepatitis C virus infection in the United States. Clin Infect Dis. 2014;59(6):755-64. doi:10. 1093/cid/ciu427. Epub 2014 Jun 9.

40. Razavi H, Elkhoury AC, Elbasha E, Estes C, Pasini K, Poynard T, Kumar R. Chronic hepatitis C virus (HCV) disease burden and cost in the United States. Hepatology. 2013;57(6):2164-70. doi:10.1002/hep.26218. Epub 2013 May 6.

41. Smith B, Morgan R, Beckett G, Falk-Yetter Y, Holtzman D, Teo C, et al. Recommendations for the identification of chronic hepatitis $C$ virus infection among persons born during 1945-1965. MMWR Recomm Rep. 2012;61(RR-4);1-32.

42. Moyer VA. Screening for Hepatitis C Virus Infection in Adults: U.S. Preventive Services Task Force Recommendation Statement Ann Intern Med. 2013; 159(5):349-58

43. Ware JE, Kosinski M. Interpreting SF-36 summary health measures: a response. Qual Life Res. 2001;10(5):405-13. discussion 415-20.

44. Younossi ZM, Guyatt G, Kiwi M, Boparai N, King D. Development of a disease specific questionnaire to measure health related quality of life in patients with chronic liver disease. Gut. 1999:45(2):295-300.

45. Younossi ZM, Stepanova M, Henry L. Performance and Validation of Chronic Liver Disease Questionnaire-Hepatitis C Version (CLDQ-HCV) in Clinical Trials of Patients with Chronic Hepatitis C. Value in Health 2016 (In Press).

46. Webster K, Odom L, Peterman A, et al. The Functional Assessment of Chronic Illness Therapy (FACIT) measurement system: Validation of version 4 of the core questionnaire. Qual Life Res. 1999;8(7):604.

47. Reilly MC, Zbrozek AS, Dukes EM. The validity and reproducibility of a work productivity and activity impairment instrument. Pharmaco Economics. 1993:4:353-65.

48. Chou R, Clark E, Helfand.Screening for Hepatitis C Virus Infection- Systematic Evidence Reviews, No. 24. http://www.ncbi.n/m.nih.gov/books/NBK43249/.

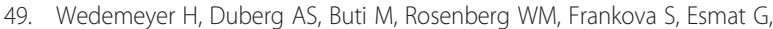
Örmeci N, et al. Strategies to manage hepatitis C virus ( $\mathrm{HCV}$ ) disease burden. J Viral Hepat. 2014;21 Suppl 1:60-89. 10.1111/jvh.12249.

50. Razavi H, Bruggmann P, Wedemeyer H, Dore G. Response to letter to the editor: Strategies to reduce HCV disease burden and HCV transmission need different models, as what works for end-stage liver disease may not work for HCV prevalence: a comment on the results presented in JVH Special Issue. J Viral Hepat. 2014;21(12):e169-70. doi: 10.1111/jvh.12339. Epub 2014 Sep 29.

51. Rodger AJ, Jolley D, Thompson SC, Lanigan A, Crofts N. The impact of diagnosis of hepatitis C virus on quality of life. Hepatology. 1999; 30(5):1299-301.

52. Loria A, Doyle K, Weinstein AA, Winter P, Escheik C, Price J, Wang L, Birerdinc A, Baranova A, Gerber L, Younossi ZM. Multiple Factors Predict Physical Performance in People with Chronic Liver Disease. Am J Phys Med Rehabil. 2014 Jan 6. [Epub ahead of print].

53. Kallman J, O'Neil MM, Larive B, Boparai N, Calabrese L, Younossi ZM. Fatigue and health-related quality of life (HRQOL) in chronic hepatitis $C$ virus infection. Dig Dis Sci. 2007;52(10):2531-9. Epub 2007 Apr 4.

54. Boscarino JA1, Lu M, Moorman AC, Gordon SC, Rupp LB, Spradling PR, Teshale EH, Schmidt MA, Vijayadeva V, Holmberg SD. Predictors of poor mental and physical health status among patients with chronic hepatitis C infection: The chronic hepatitis cohort study (CHeCS). Hepatology. 2014 Sep 9. doi: 10.1002/hep.27422. [Epub ahead of print]. 